\title{
Extraction Methods of Spanish Broom (Spartium Junceum L.)
}

\section{Metode ekstrakcije brnistre ili žuke (Spartium Junceum L.)}

\author{
Original scientific paper • Izvorni znanstveni rad \\ Received-prispjelo: 28. 3. 2011. \\ Accepted-prihvaćeno: 22. 11. 2011. \\ UDK: $630 * 874$ \\ doi:10.5552/drind.2011.1112
}

\begin{abstract}
Effects of different extraction methods of the Spanish Broom shoots were measured and compared with the purpose of obtaining composite material. The content of cellulose, lignin, pentosan and ash in the Spanish Broom fibers was determined. SEM analyses were performed.
\end{abstract}

Keywords: Spanish Broom fibers, fiber extraction, chemical composition, FTIR, MW

SAŽETAK • Mjereni su i uspoređeni učinci različitih postupaka maceracije izbojaka brnistre, radi upotrebe prirodnih vlakana u procesu dobivanja kompozitnih materijala. Uspoređeni su FTIR spektri nekih prirodnih vlakana, kao i FTIR spektri vlakana dobivenih različitim postupcima maceracije. U vlaknima brnistre određen je sadržaj celuloze, lignima, pentosana i pepela. Obavljene su SEM analize izbojka brnistre.

Ključne riječi: vlakna brnistre, maceracija, kemijska kompozicija, FTIR, MW

\section{INTRODUCTION 1. UVOD}

The use of Spanish Broom and its diverse application has been known in the entire Mediterranean since the ancient times. Already in the ancient Rome, where Spanish Broom fields (genestium - or ager in later Latin) were cultivated as any other field, and the plant or sprouts were sown in ploughed up furrows, as the Roman agronomist Columella describes. According to Vergil, hedges of Spanish Broom were planted in addition to willow, hazel, elder and other plants. Pliny writes that the sowing and planting of Spanish Broom is crucial for peasants. Amongst other things, its branches provide excellent material for tying vine and young trees. The Greeks, Romans and Carthagians used Spanish Broom as raw material for manufacturing ropes, nets, bags, sails, clothing and for covering roofs, whilst the flower of Spanish Broom produces exquisite honey.

During the ' 30 s of the past century, foresters widely recommended the cultivation of Spanish Broom (Spartium junceum) in the coastal karst areas, more precisely M. Anić Ph. D in The Forest Journal in 1937 and engineer Stane Benko in his booklet on Spanish Broom, published by the Ministry of Industry and Mining, in Zagreb, 1946. The member of the Institute for Forestry Research Ante Premužić explains the possibility of using Spanish Broom for economic purposes in his report Systematic cultivation of Spanish broom in our karst areas, published in the Forest Journal. He wrote that diverse biological properties could be put to

\footnotetext{
${ }^{1}$ Author is professor at Faculty of Textile Technology, University of Zagreb, Zagreb, Croatia. ${ }^{2}$ Author is assistant professor at Faculty of Engineering, Department of Chemical Engineering and Materials, University of Calabria, Italy. ${ }^{3}$ Author is assistant professor at Faculty of Forestry, University of Zagreb, Zagreb, Croatia.

${ }^{1}$ Autor je profesor Tekstilno-tehnološkog fakulteta Sveučilišta u Zagrebu, Zagreb, Hrvatska. ${ }^{2}$ Autorica je docent Tehničkog fakulteta Kalabrijskog Sveučilišta, Italija. ${ }^{3}$ Autor je docent Šumarskog fakulteta Sveučilišta u Zagrebu, Zagreb, Hrvatska.
} 
good use for forestation of poor soil of the coastal limestone area since Spanish Broom grows on clay and limestone soil of neutral, acid and alkali reaction. Positive sides of its cultivation were highly praised, giving these studies more of a propaganda character. The use of Spanish Broom along east Adriatic was described in detail in the publications of the Faculty of Philosophy, Zagreb University (Stojanović, 1962). Notwithstanding all that, the application of Spanish Broom, as raw material, is almost forgotten today. The entire activity has been reduced to a few associations more of a tourist significance (Katović at al, 2011).

During the past several years the number of scientific work related to the production of Spanish Broom as raw material in the manufacture of composite materials considerably increased (Avella et al, 1998; Angelini et al, 2000; Gabriele et al, 2010; Cerchiara et al, 2010 A). The advantage of Spanish Broom over flax and hemp is that it can grow in the most unfavorable limestone soil; it is resilient to draught; and once planted it can be used during a period of up to twenty years, whilst flax and hemp demand high quality soil each year. In the past, natural fibers were not taken into account as reinforcements for polymeric materials because of certain problems associated with their use. The lack of good interfacial adhesion, low degradation temperature, properties variability depending on harvest quality, age and body of the plant, and poor resistance towards moisture make the use of natural fiber reinforced composites less attractive than the synthetic ones. However, the production of composites reinforced with synthetic fibers and matrices (glass, carbon, aramid) requires a large amount of energy, and they are impossible or hard to recycle. Moreover, in case of fire the presence of natural fibers in composites decreases the content of toxic gases resulting from combustion.

\section{MATERIALS AND METHODS}

\section{MATERIJALI I METODE}

\subsection{Spanish Broom - biological properties}

2.1. Brnistra - biološka svojstva

Spanish Broom is a shrub like plant from the family of legumes. It is the only species in the genus Spartium. Spanish Broom is a shrub that grows 1-1.5 meters tall and only old examples grow into smaller trees between 4 and 5 meters tall and 15 to 20 centimeters thick. Spanish Broom produces intensively yellow flowers between May and July, and its legumes mature between August and October. Flowers have male and female organs pollinated by insects. It has many flowers, one to two centimeters in diameter that cover hills, turning into a beautiful yellow color, whilst its pleasant fragrance is especially loved by women. Spanish Broom most often grows in fresh and sufficiently moist soil, but it also grows quite well in very dry and rocky soil, stone falls and flood gravel pits. Shade does not suit it. It also has a special feature of xerophile plants. It grows small leaves on its shoots, which it discards during summer and drought and assimilates with long thin shoots, which have nuclei with chlorophyll under the cuticulum. Its roots are deep, and it binds the soil quite well. As a legume plant, it uses symbiosis to bind atmospheric nitrogen in the roots' lumps, thickening and enriching the soil (Bezić et al, 2003). After fiber extraction, it can be used in the production of textile fibers, just as hemp and flax. Its habitat is the Mediterranean area of the South Europe, southwest Asia and North West Africa. In Italy, in the Mediterranean area of olive groves, it climbs the altitude of 975 meters. In Turkey, Syria and Palestine, it reaches altitudes of 1,700 meters. It is regarded weed in the USA and New Zealand with a tendency to eradicate it in order to save indigenous plants.

Numerous anatomical adaptations to arid habitat can be noted in the microscopic structure of vegetative organs of Spanish Broom. The xerophytic (xerophytes - plants adapted to dry habitats) adaptation of the leaf is seen in its short life span as well as the transformation of its inner structure, with the dominating parenchyma chain. The top of the stem has taken over the leaf function, whilst the sclerenchyma fiber and conductive elements occupy most of its secondary units (Cerchiara et al, 2010 A).

After the maturing of seeds, between mid July and autumn, shoots of the plant are cut with scissors directly near the main tree (Kovačević et al, 2010).

\subsection{Instruments}

2.2. Instrumenti

\subsubsection{FTIR (Fourier Transform Infra Red} Spectrophotometer)

2.2.1. FTIR (Furierov transformirajući infracrveni spektrofotometar)

The instrument is used in infrared spectroscopy for the identification of unknown material, for determining the ratio of individual components in the sample, its quality and consistency. Infrared beams pass through the sample. Some of the beams are absorbed in the sample and others pass through it, creating a spectrum unique to each element. Perkin-Elmer FT-IR Spectrum 100 was used for the purpose of work. Before the measuring, Spanish Broom samples were turned into powder, using a grinder with an oscillating steel bowl, model MM 400, of the Retsch company. The measuring was performed by FTIR spectrometer using ATR technique.

\subsubsection{TA (Thermal Analyzer) \\ 2.2.2. TA (termogravimetar)}

The pyrolysis characteristics of Spanish broom, hemp and flax were analyzed using a thermogravimetric analyzer PerkinElmer Pyris 1 TGA. The samples, weighing between 4 and $5 \mathrm{mg}$ were stacked in an open platinum sample pan and the experiment was conducted in air atmosphere. All samples for TGA were measured from $50{ }^{\circ} \mathrm{C}$ to $800{ }^{\circ} \mathrm{C}$ at the heating rate of $10^{\circ} \mathrm{C} / \mathrm{min}$.

\subsubsection{SEM (Scanning Electron Microscope)}

2.2.3. SEM (skenirajući elektronski mikroskop)

Morphological structures of Spanish Broom shoots were recorded with the FE-SEM (Field Emission-Scanning Electron Microscope) of the company 
TESCAN, with a steamer and unit for EDX analysis (Energy Dispersive X-Ray Analysis). Before of the microscopic recording, samples were processed for 180 seconds in a steamer with gold and palladium, using operative voltage of $5-15 \mathrm{kV}$.

\subsection{Methods}

\subsection{Metode istraživanja}

The Spanish broom fibers were extracted from the plant branches harvested in Dalmatia (Šibenik area) which contained $35 \%$ of humidity in relation to the branches dried under standard conditions.

Fig. 1 clearly shows that Spanish Broom shoots have two basic layers: rigid and woody inner layer, porous in the middle, which makes the plant quite light; and an outer layer, or rather skin consisting of stringy fibers. Here, the lignin is a typical chemical and morphological part of the fiber, which provides rigidity and conducts fluids.

Methods for determining the content of cellulose, lignin, woody polyoses (hemicellulose), extracting substances and ash content were conducted in compliance with the regulations previously described in this journal (Antonović et al, 2007).

Effects of different types of the Spanish Broom shoots extraction were examined in the work in terms of quality and quantity of the obtained fibers:

A. Fiber extraction in seawater: Freshly picked Spanish Broom shoots were tied in a bundle, weighing $100 \mathrm{~g}$ and then soaked in water for 21 days. After resting in seawater, at the average temperature of $22{ }^{\circ} \mathrm{C}$, the fibers were separated from the woody part by rubbing against stone plates. They were rinsed in seawater and then the fibers started to separate from the woody part. Before the examination, the fibers were dried in standard conditions. The content of the obtained fibers stood at approximately $12 \%$ of the total weight of the dry shoots.

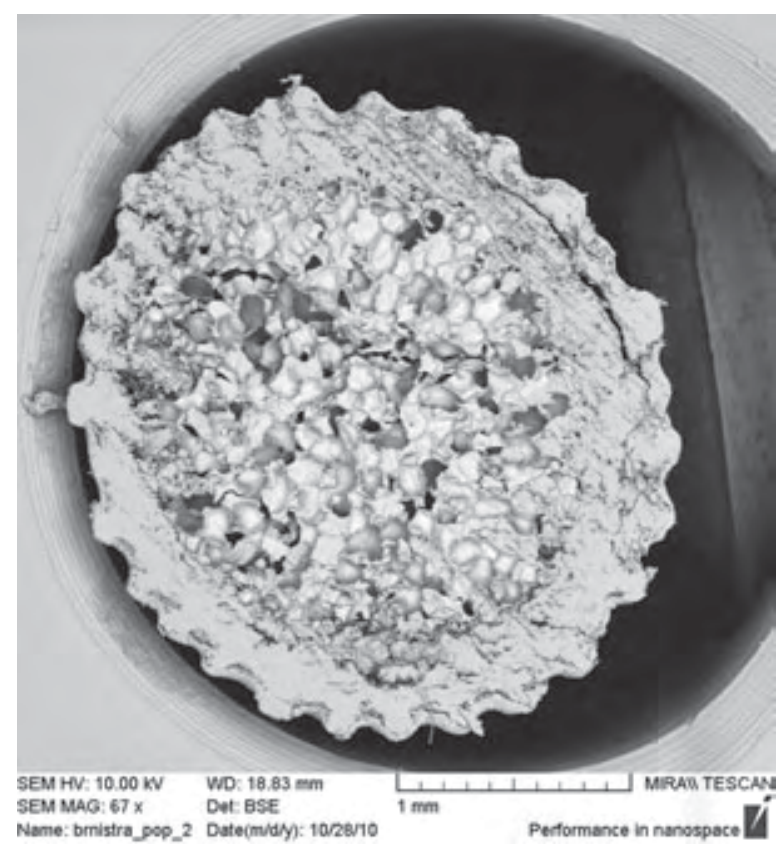

Figure 1 SEM micrograph of cross-section of Spanish Broom shoot

Slika 1. SEM slika poprečnog presjeka izbojka brnistre
B. Samples extracted in a solution of $15 \mathrm{~g} / \mathrm{l}$ sodium alkali: Freshly picked Spanish Broom samples were tied in bundles ( $100 \mathrm{~g})$ and processed during three hours at $120{ }^{\circ} \mathrm{C}$. After the processing, the fibers easily separated from the woody part. Before the examination, the fibers were dried in standard conditions. The content of the obtained fibers stood at approximately $30 \%$ of the total weight of the dry shoots. (Cerchiara et al, 2010 B)

C. Samples extracted using the $\mathrm{DiCoDe}$ procedure: Freshly picked Spanish Broom samples were tied in bundles (100 g) and processed during 15 minutes at $100{ }^{\circ} \mathrm{C}$. After being processed in the alkali, the fibers were rinsed in distilled water to the level of neutral, and then put in moist conditions in an autoclave at $120{ }^{\circ} \mathrm{C}$ and pressure of 10 atmospheres during three hours. Quick decompression followed. Afterwards, the fibers easily separated from the woody part. Before the examination, the fibers were dried in standard conditions. The content of the obtained fibers stood at approximately $30 \%$ of the total weight of the dry shoots.

D. Extraction by microwave application: This is a new patented extraction procedure, developed at the Institute for Textile Chemical Technology and Ecology of the Zagreb University - Faculty of Textile and Technology. For the purpose of this study, a Teflon reactor, inert to microwave activity, of the total volume of 500 $\mathrm{ml}$, was constructed. 50 grams of Spanish Broom shoots and $300 \mathrm{ml}$ of $15 \% \mathrm{NaOH}$ solution were put in the Teflon reactor and then in a microwave oven set to $900 \mathrm{~W}$, for a period of 10 minutes. After being processed under the influence of the microwaves, the samples were rinsed in hot and then cold distilled water. After the rinsing, the fibers easily separated from the woody part. The content of the obtained fibers stood at approximately $30 \%$ of the total weight of the dry shoots.

\section{RESULTS AND DISCUSSION 3. REZULTATI I DISKUSIJA}

The IR spectra of the fiber sample obtained after alkaline extraction was recorded on the ATR-FTIR spectrometer (Spectrum 100, Perkin Elmer), while cotton, flax and hemp fibers were taken as reference samples. From the recorded FT-IR spectra of the fiber samples, it can be seen that all fibers have peak characteristic for cellulose although they present some differences (Fig. 2.). The intensity of the signal at $1734 \mathrm{~cm}^{-1}$ corresponding to the $\mathrm{C}=\mathrm{C}$ esther band related to pectin is higher in flax than in hemp fibers, while this band is not found in Spanish broom fiber sample. On the contrary, only a weak peak at ca. $1500 \mathrm{~cm}^{-1}$ corresponding to the $\mathrm{C}=\mathrm{C}$ in-plane aromatic vibrations from lignin can be observed in the case of Spanish broom fibers, providing an ulterior evidence that the applied chemical treatment was adequate for the almost complete removal of the non-cellulosic compounds from the broom fibers. On the other hand, the two little sharp peaks observed over a broader peak in the area of 2850 to $2950 \mathrm{~cm}^{-1}$, attributed to the $\mathrm{CH}_{2}$ and $\mathrm{CH}$ groups of long alkyl chains of waxes, are present in the spectra of flax and hemp. 


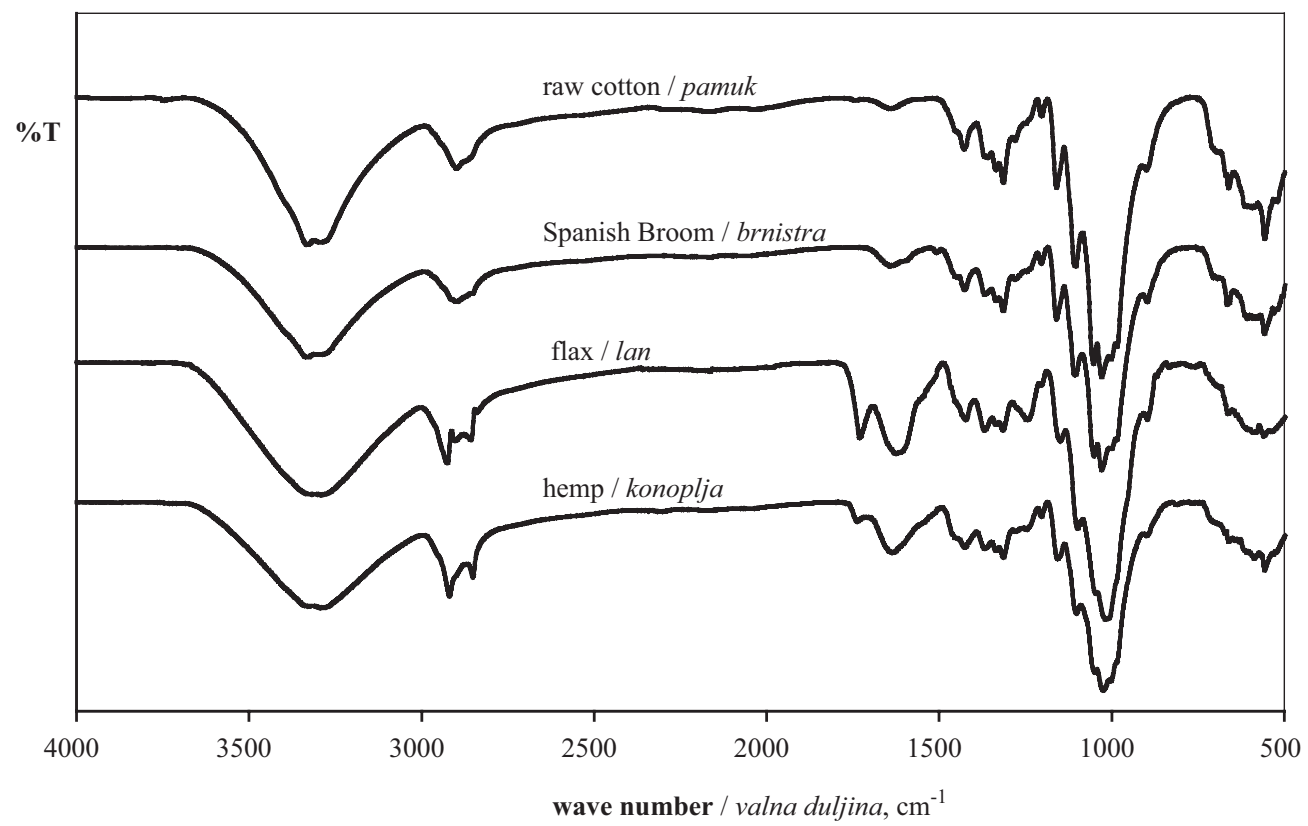

Figure 2 FTIR (Fourier Transform Infra Red) spectra of some bast fibers compared to the cotton fiber Slika 2. FTIR (Fourier Transform Infra Red) spektri nekih stabljičnih vlakana u usporedbi s pamučnim vlaknom

Fig. 3 shows TG spectra together with the corresponding DTG curves of some bast fibers. The TG curve can be divided with respect to the three temperature ranges. A slight weight loss of the material is characteristic for temperatures under $200^{\circ} \mathrm{C}$, which is due to water loss in the form of absorbed moisture. In this area, weight loss of the examined material is under $10 \%$. When the temperature is between 200 and $550{ }^{\circ} \mathrm{C}$, significant weight loss is evident, which results from thermal decomposition of hemicellulose, cellulose and lignins. In this area, the weight of the examined material decreased by $70-80 \%$. When the temperature exceeds $550{ }^{\circ} \mathrm{C}$, the weight loss is not as considerable as in the previous area. This weight loss is a consequence of thermal disintegration of other heavy components. Lignin- cellulose fiber structure can be qualitatively identified using DTG curves. In other words, hemicellulose, cellulose and lignin can be distinguished from the intensity distribution of the weight loss of the tested material. Thermal disintegration of the hemicellulose takes place at temperatures between 150 and $350{ }^{\circ} \mathrm{C}$. The cellulose disintegrates at temperatures between 275 and $350{ }^{\circ} \mathrm{C}$, whilst the lignin disintegrates at temperatures between 250 and $550^{\circ} \mathrm{C}$ (Nekkaa et al, 2006; Chen et al, 2010).

The FTIR spectra of Spanish Broom fibers obtained after four different extraction procedures are presented in Fig. 4.

According to the previously highlighted peaks that point to the presence of pectin, lignin and/or wax, it can be seen that the procedure B resulted in the best

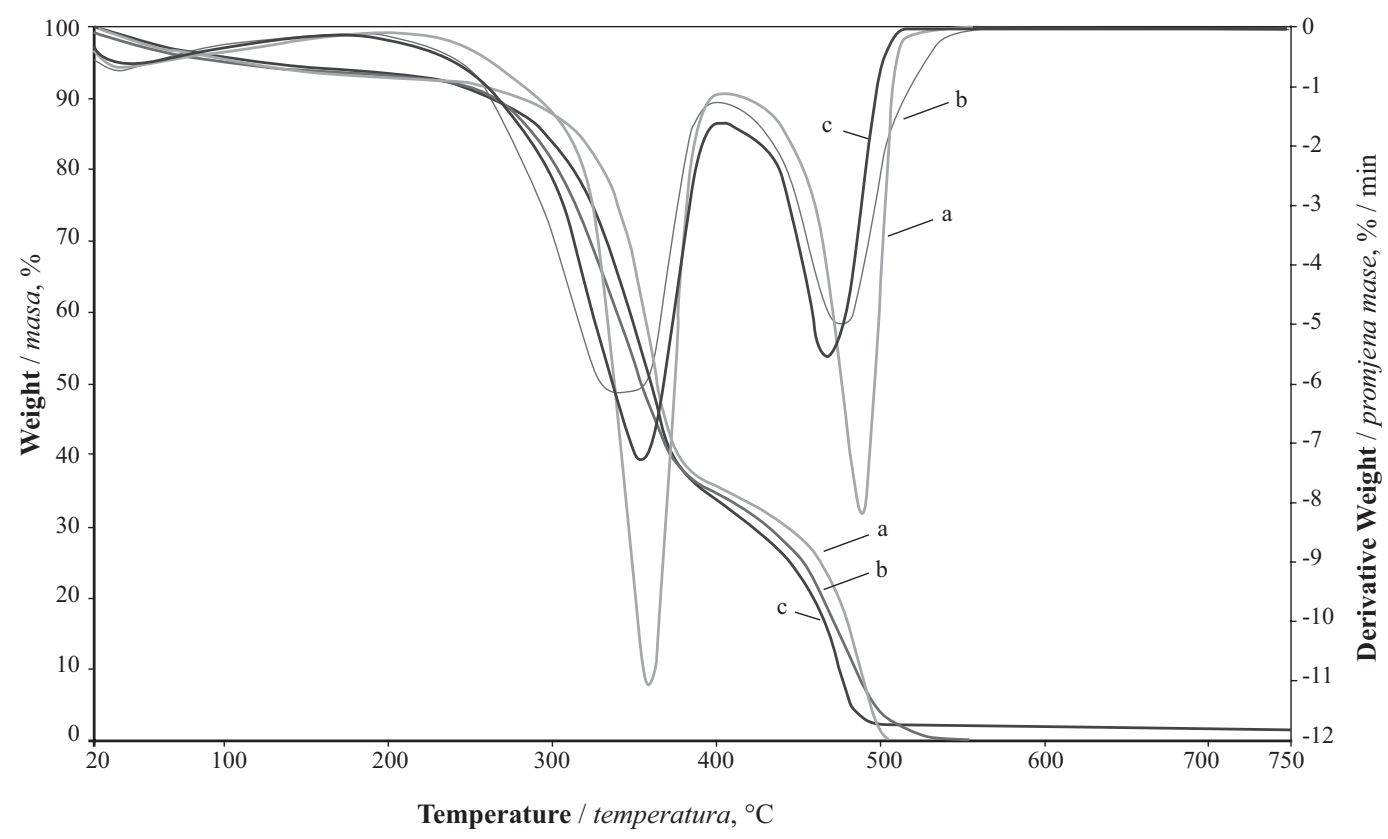

Figure 3. TG and DTG spectra of some bast fibres ( $\mathrm{a}$ - hemp, b - Spanish Broom, c - flax)

Slika 3. TG i DTG spektri nekih stabljičnih vlakana ( $\mathrm{a}$ - konoplja, $\mathrm{b}$ - brnistra, $\mathrm{c}-$ lan) 


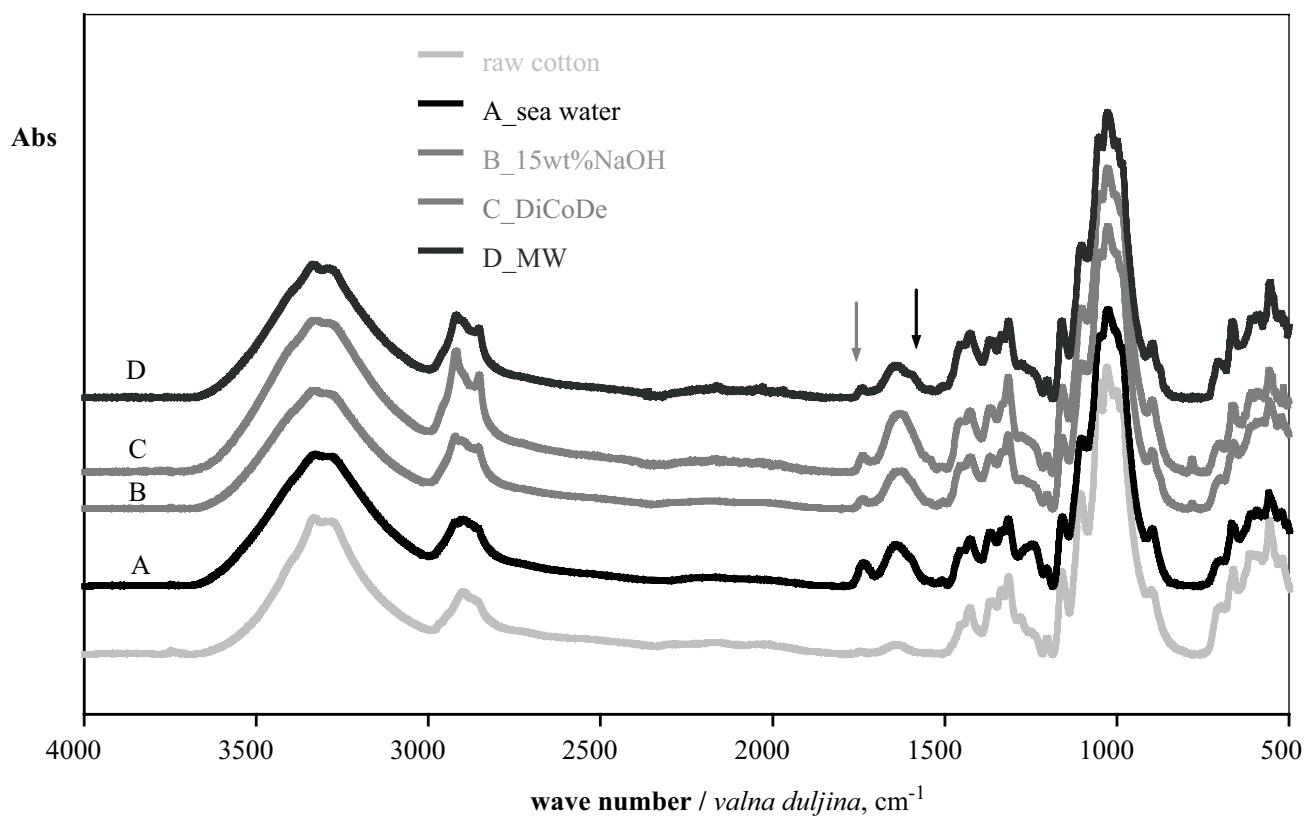

Figure 4 FTIR spectra of fibers obtained from Spanish broom plant applying four different procedures compared to the cotton fiber (A. Fiber extraction in seawater, B. Samples extracted in a solution of $15 \mathrm{~g} / 1$ sodium alkali, C. Samples extracted using the DiCoDe procedure, D. Extraction by microwave application)

Slika 4. FTIR spektri vlakana dobivenih od brnistre različitim postupcima u usporedbi s pamučnim vlaknom (A - maceracija u morskoj vodi, B - maceracija u otopini $15 \mathrm{~g} / 1$ natrijeve lužine, $\mathrm{C}$ - maceracija postupkom DiCoDe, D - maceracija primjenom mikrovalova)

removal of the non-cellulosic compounds of the fiber. Fiber treatment (B) with sodium hydroxide at $105^{\circ} \mathrm{C}$ for $2 \mathrm{~h}$ completely removes wax and lignin, whilst a weak peak related to pectin at $1740 \mathrm{~cm}^{-1}$ is still visible. On the other hand, fiber treatment (D) with the same alkaline solution, but heated in a microwave oven for only 10 minutes $(900 \mathrm{~W})$ resulted in higher removal of pectins and maybe not total elimination of lignin as seen from the broadening of the peak at $1640 \mathrm{~cm}^{-1}$ (see the shoulder towards the lower wave number values). However, the latter treatment seems very promising, especially from the economical point of view.

The chemical composition of fibers extracted by different procedures is shown in Fig. 5. The only signi-

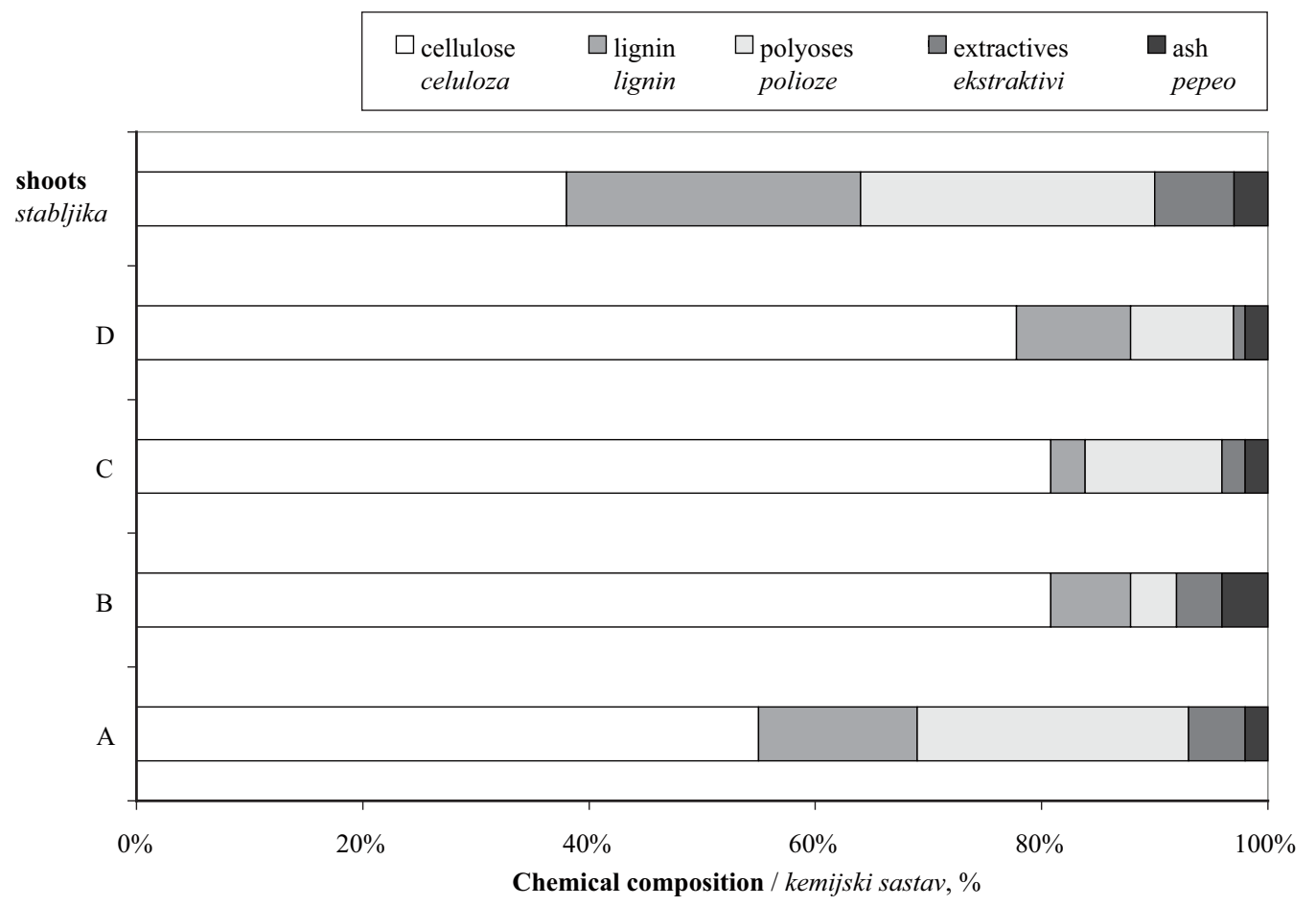

Figure 5 Chemical composition (in \%) of Spanish Broom fibers obtained by four different procedures compared to the composition of shoot

Slika 5. Kemijska kompozicija (u postocima) vlakana brnistre dobivenih nakon četiri različite metode maceracije u usporedbi sa sastavom stabljike 


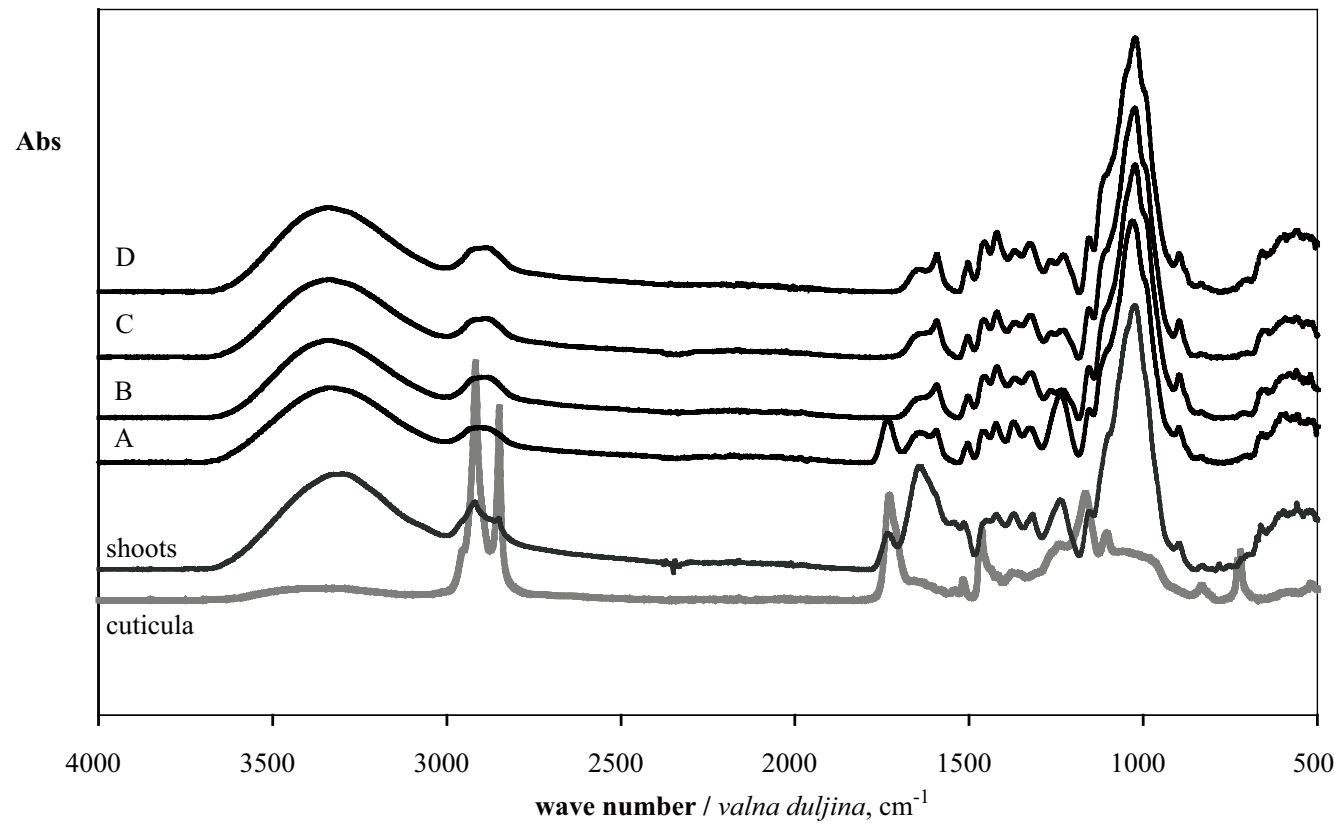

Figure 6 FTIR spectra of residues obtained after extracting fibers from Spanish Broom by four different procedures, the shoots before extraction and the cuticula.

Slika 6. FTIR spektri ostataka nakon ekstrakcije vlakana brnistre četirima različitim metodama i opne preostale nakon obrade u morskoj vodi

ficant difference is observed in the case of the procedure A for which the lowest amount of cellulose is found and the resulting high amounts of lignin, polyoses as well as extractives confirm the observation made from the FTIR spectrum of the Spanish Broom fibers obtained by sea water extraction procedure. The results of the remaining three procedures are equally good with respect to the cellulose content of the fiber, approxima- tely $80 \%$, whilst the content of the residuals differs from procedure to procedure. In the case of procedure $\mathrm{B}$ a kind of equality in the amounts of lignin, polyoses and extractives is found out, while the fibers obtained by applying the procedures $\mathrm{C}$ and $\mathrm{D}$ show different distribution among lignin, polyose and extractive amounts. In the case of the procedure $\mathrm{C}$, the amounts of lignin and extractives are almost equivalent; whilst the con-

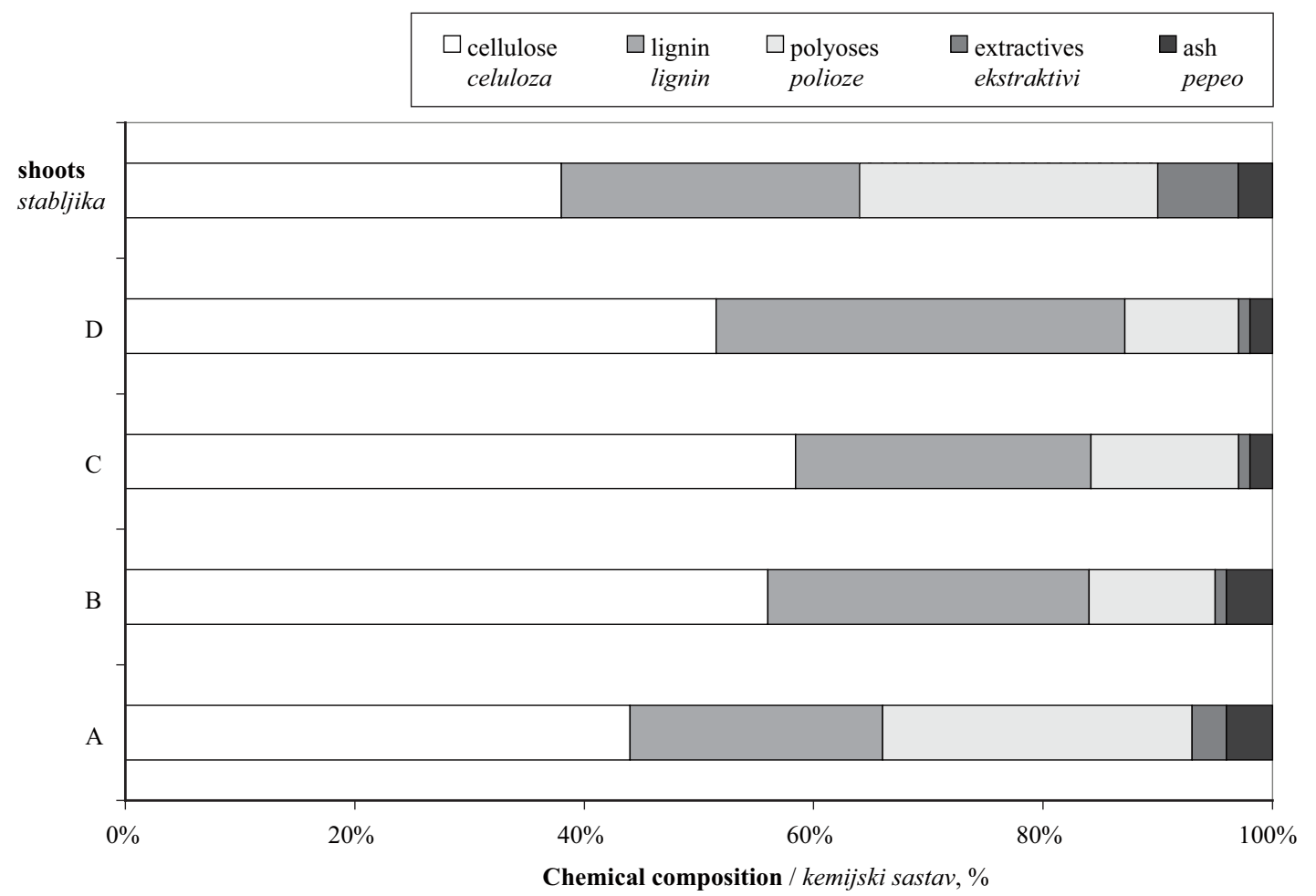

Figure 7 Chemical composition (in \%) of residues left after extraction of Spanish Broom fibers obtained by four different procedures compared to the composition of shoots.

Slika 7. Kemijska kompozicija (u postocima) ostatka nakon maceracije vlakana brnistre dobivenih nakon četiri različite vrste maceracije 
tent of polyoses is relatively high i.e. two times the former two components. For the microwave procedure (D), the lignin and polyoses amounts are comparable whereas the extractive content is very low.

Samples of the remaining material after the extraction of fibers from the Spanish Broom shoots were also examined.

Fig. 6 clearly shows that wax is the major component of the cuticula (vermenes membrane), i.e. two sharp peaks at 2850 and $2920 \mathrm{~cm}^{-1}$, respectively. Other samples present more or less pectin and/or lignin, while the predominant part are cellulosic components having a lower degree of crystallinity as it appears from the shape of the main peak at ca. $1030 \mathrm{~cm}^{-1}$, one of the $\mathrm{C}-\mathrm{O}$ stretching modes characteristic of cellulose, which is smoother presenting only shoulders at ca. $1155 \mathrm{~cm}^{-1}$ and $1105 \mathrm{~cm}^{-1}$ corresponding to the $\mathrm{C}-\mathrm{C}$ ring breathing and the $\mathrm{C}-\mathrm{O}-\mathrm{C}$ glycosidic ether band.

The evaluation of the FTIR spectra is confirmed by the chemical composition analyses presented in Fig. 7. The presented results are similar to those found in literature i.e. with respect to the fibre extraction procedure, the cellulose amount changes from 66.9 to $91.7 \%$ in the case of mechanical and physicochemical procedure, respectively (Cerchiara et al, 2010 B) or 74.1\% as reported by Angelini et al. (2000) for mechanically obtained fibres. The same trend is valid for the lignin amount, which is always lower for the fibers extracted by non-mechanical procedures.

\section{CONCLUSIONS}

\section{ZAKLJUČCI}

The comparison between water fiber extraction and $\mathrm{NaOH}$ solution proved that the procedures in $\mathrm{NaOH}$ solution result with a significantly higher quantity of fiber bundles in relation to water fiber extraction. In all three cases of solution related processing, the quantity of fibers and the remainder after the extraction is similar. Extraction by microwaves requires the smallest amount of energy and the shortest processing period.

The structure of the Spanish Broom fibers can be qualitatively identified using DTG curves. Hemicelluloses, celluloses and lignin can be distinguished from the intensity distribution of the weight loss of the tested material since thermal decomposition of cellulose occurs at different temperatures.

FT-IR specters of the fibers cotton, hemp, flax and Spanish Broom have peak characteristic for cellulose although they present some differences.

\section{Acknowledgments - Zahvala}

The research leading to these results has received funding from the European Community's Seventh Framework Programme (FP7/2007-2013) for the CSA action FP7-REGPOT-2008-1:T-Pot for grant agreement no. 229801

\section{REFERENCES 5. LITERATURA}

1. Angelini, L.G.; Lazzeri, A.; Levita, G.; Fontanelli, D.; Bozziu, C., 2000: Ramie (Boechmeria nivea (L) Gaud.) and Spanish Broom (Spatrium junceum L.) fibres for composite materials: agronomical aspect, morphology and mechanical properties. Industrial Crops and Products $11,145-161$,

http://dx.doi.org/10.1016/S0926-6690(99)00059-X

2. Antonović, A.; Jambreković, V.; Pervan, S.; Ištvanić, J.; Moro, M.; Zule, J., 2007: Utjecaj lokaliteta uzorkovanja na grupni kemijski sastav bijeli bukovine (Fagus sylvati$c a$ L.) Drvna industrija 58 (3): 119-125.

3. Avella, M.; Casale, L.; Dell'Erba, R.; Focher, B.; Martuscelli, E.; Marzetti, A.M., 1998: Broom Fibers as Reinforcing Materials for Polypropylene-Based Composites J. Appl Polym Sci 68, 1077-1089, http://dx.doi.org/ 10.1002/(SICI) 1097-4628(19980516)68:7<1077:: AID-APP5>3.0.CO;2-C

4. Bezić, N.; Dunkić, V.; Radonić, A., 2003 Anatomical and chemical adaptation of Spartium junceum L. in arid habitat. Acta Biologica Cracoviesia, Series Botanica 45/2, 43-47.

5. Cerchiara, T.; Chidichimo, G.; Ragusa, M.I.; Belsito, E.L.; Liguori, A.; Arioli, A., 2010A: Characterization and utilization of Spanish Broom (Spartium junceum L.) seed oil. Industrial Crops and Products 31, 423-426, http://dx.doi.org/10.1016/j.indcrop.2009.11.003

6. Cerchiara, T.; Chidichimo, G.; Gallucci, M.C.; Vuono, D., 2010B: Effects of Extraction (Spartium junceum L.) Fibres. Fibres \& Textiles in Eastern Europe 2 (79): 13-16.

7. Chen, W.H.; Kuo, P.C., 2010: A study on torrefaction of various biomass materials and its impact on lignocellulosic structure simulated by a thermogravimetry. Energy: 35, 2580-2586, http://dx.doi.org/10.1016/j.energy.2010.02.054

8. Gabriele, B.; Teresa Cerchiara, T.; Salerno, G.; Chidichimo, G.; Vetere, M.V.; Alampi, C.; Gallucci, M.C.; Conidi, C.; Cassano, A., 2010: A new physical-chemical process for the efficient production of cellulose fibers from (Spartium junceum L.). Bioresource Technology 101, 724-729,

http://dx.doi.org/10.1016/j.biortech.2009.08.014

9. Katović, D.; Katović, A.; Krnčević, M., 2011: Spanish Broom - History and Perspective (Spartium Junceum). Journal of Natural Fibers - in press.

10. Kovačević, Z.; Krnčević, M.; Katović, A.; Katović, D., 2010.: Brnistra - zaboravljena tekstilna sirovina, Tekstil 59 (9): 410-421.

11. Nekkaa, S.; Chebira, F.; Haddaoui, N., 2006: Effect of Fiber Treatment on the Mechanical and Rheological Properties of Polypropylene/Broom Fiber (Spartium Junceum) Composites. Journal of Engineering and Applied Sciences 1(3); 278-283.

12. Stojanović, A., 1962: Brnestra (Žuka - Spartium Junceum). Etnološki Zavod Filozofskog fakelteta Sveučilišta u Zagrebu, Izdavački zavod Jugoslavenske akademije znanosti i umjetnosti u Zagrebu.

\section{Corresponding address:}

Prof. DRAGO KATOVIĆ Ph.D.

Universty of Zagreb

Faculty of Textile Technology

Department of Textile Technology and Eccology

Zagreb, Savska cesta 16/9, CROATIA

e-mail: dkatovic@ttf.hr 